\title{
Analysis on the Risk Control and Development Strategy of Futures Company in China
}

\author{
Xiaoming Qiao \\ Journal Editorial Department, Yunnan Normal University, Kunming, 650092, Yunnan, China
}

Keywords: Futures Company, Risk, Market

\begin{abstract}
With the bridge between the market and investors, futures companies face considerable risks when conducting business activities, such as market risk, investor credit risk and internal practitioners operating risk. Efficient risk control is the premise of futures company to maintain sustainable management and further innovation and development. At present, there are still some deficiencies in the external regulatory environment of risk management in futures company , such as the desperation of the authority and responsibility, but it tends to be optimized. Deficiencies still exit in futures company internal risk control mechanism, because of the inadequate corporate governance, the single mode of risk management, the lack of risk assessment tool, seriously affecting the normal operation of futures company. Therefore, it is necessary to set up an independent futures regulatory authority to strengthen supervision at the legal level. Secondly, it is important to establish long-term risk supervision mechanism, improve the corporate governance structure, adjust the business structure and strengthen the internal staff management on the futures company side.
\end{abstract}

\section{Introduction}

Since 2007, the State Council and relevant regulatory authorities have issued a series of policies and regulations to standardize the development of the industry and create a favorable policy environment for futures companies. Its main function is to regulate the development of the industry, encourage business innovation, strengthen market risk monitoring and help enhance the company's operation and profitability. From the classification results of the futures companies in 2016, the number of AA-based companies was 10, down significantly from 2015. The number of companies rated A dropped from 44 to 30 and the number of Class B companies increased from 88 to 102 Home. In recent years, the futures companies have gradually expanded their business innovation and their business risks have risen accordingly. The overall decline of the classification ratings reflects the tight supervision and guidance to a certain extent on the standardization of futures companies. The current futures company's wind control construction there are still quite a problem, how to effectively control the risk of a futures company a major business problems, high operational risk not only limited to the sustainable management of futures companies, but also hindered innovation and development. In 2012, 18 futures companies were approved to carry out the asset management business in pilot form. In 2014, the mid-term agreement further liberalized the "one-to-many" business model and the industry has a bright future. As of the end of June 2016, the size of the asset management business of futures companies was as high as 227.3 billion RMB, an increase of $62.59 \%$ over the first quarter, an obvious increase. In addition, in mid-2012, the futures industry approved the provision of risk management services in the form of subsidiaries. According to the statistics, the total assets of the risk management subsidiaries in 2014 were 6.694 billion RMB and the business income was 19.799 billion RMB. In 2015, the asset scale reached 11.348 billion RMB, an increase of $69.52 \%$ over the same period of last year. The business income increased to 37.466 billion RMB, an increase of $89.23 \%$ over the previous year. The development of innovative businesses is an important way for futures companies to maintain their competitiveness in the current period. However, it is undeniable that innovative businesses have also accumulated considerable risks for futures companies, threatened the normal operation of futures companies and made effective control of risks the current futures industry an important 
strategic consideration.

\section{The Literature Review}

\subsection{The Source and Composition of Futures Company Risk}

Zhang Pei RMB (2008) argues that there are risks of spot transfer, transaction and politics in the futures market, and the risks accumulated by them are transmitted to the futures companies. The futures companies passively assume and manage the risks, so the risk is precisely because of their special financial market position Initiated [1]. Guo Rui (2005) proposed that the sources of risk of futures companies include both internal and external sources. The external causes mainly lie in the imperfect laws and regulations, the imperfect regulatory system, the lack of financing channels and the harsh competition environment. The internal factors include the scale, business scope, internal control mechanism and management tools and other negative defects [2]. Li Yan (2015) argues that the risk of futures companies is triggered by the particularity of futures trading and its inherent defect management system, involving a series of risk types such as market risk, operational risk, liquidity risk and policy risk [3].

\subsection{Analysis of the Current Situation of Futures Company Risk Management}

Huang Xiaolong and Tian Zheng (2010) argue that the common defects in risk management at present in Chinese futures industry are the fragmentation of risk management, the lax implementation of risk control and the lack of awareness of risk awareness by the management of the company [4]. Chen Yueming (2015) believes that the current awareness of risk control in the futures industry is generally high, but the internal control system has not been implemented, and there are still irregularities in the actual business operations. Under the influence of market competition pressure, the futures company may Relaxing the requirement for client margin therefore magnified the risk [5]. Zhao Xianghua (2011) argues that the risks of futures companies are mainly caused by the defects of governance structure, credit problems of customers and the professional quality of internal staff. The importance of SPAN systems and VAR methods in risk measurement is emphasized [6].

\subsection{Analysis on the Risk Management and Control Strategy of Futures Companies}

Tian Tian (2014) argues that futures companies should implement the chief risk officer system in terms of risk management and control, set up a chief risk officer and supervise the company's specific operating activities and pay attention to the control of customer risks and the maintenance of their relationship [7]. From the perspective of futures companies serving entity enterprises, Zhang Jinyu (2012) proposed the significance of risk management and control strategy for futures companies in specific hedging businesses, and put forward the importance of risk identification and risk quantification [8]. Yi Yang (2013) is mainly based on the financial risks of futures companies, put forward the risk aversion should take into account the headquarters of the futures company and its branches, improve the internal control system based on improving the quality of the company's business staff to create a professional team of wind control [9].

Futures companies risk many causes, the market, customers and internal institutional factors are likely to pose a threat to the normal operation of futures companies, futures companies risk control is essential. Scholars have made a detailed analysis of the sources of the futures companies 'risks and the status quo of their control, and concluded that the main problems of the current futures companies' risk management are the conclusions of the deficiencies in the external supervision and internal management, and the related strategic analysis. However, with the rapid development of the futures industry, the futures companies are proactive in advancing business transformation and actively developing innovative businesses such as asset management and risk management. At the same time, external supervision is also becoming more mature. However, the lagging external environment and internal governance environment research have been in conflict with the current futures the status quo of the Company's risk management shows a certain degree of disjunction, so 
it cannot provide prompt suggestions on risk control for the industry. The establishment of an efficient risk control mechanism for futures companies depends on a deep cognition of the causes of risks and the importance of risk control measures. Therefore, it is necessary for the current development to study the current situation of wind control in the futures industry and put forward specific risk control strategies for our futures companies according to the developed market experience. It is very important for regulating the development of the industry and improving the sustainable management ability of futures companies.

\section{The Futures Company Risk Control Analysis}

\subsection{Futures Company Risk Control Importance of Analysis}

(1) Efficient risk control is the prerequisite for the sustainable management of futures companies. The current futures company's main business brokerage business, by accepting investors in the seat of the exchange commission, the agency involved in futures trading activities, and receive commissions. Futures trading is based on the principle of leverage and has high risks. Futures are highly mobile. Therefore, futures companies are highly vulnerable to the cumulative risks in the market and cause serious financial problems as well as crisis of customer confidence, resulting in the business activities of futures companies Bad influence, even lead to bankruptcy. Futures companies in the daily operations of the risks involved in market risk, credit risk and operational risk, market conditions change, customer credit and staff quality and other factors are the company's potential source of risk for the futures company's impact through its business activities As a result, efficient risk management becomes a prerequisite for the sustainable operation of futures companies. Taking "Haikou Wanhui" as an example, the chaotic governance structure of futures companies and the negligence of risk management and control resulted in the misappropriation of investor's security deposit and the occurrence of the absconded by management personnel. Thus, the normal operation of futures companies depends on efficient Risk control.

(2) Efficient risk control is the basis for the innovation and development of futures companies. The traditional profit model of futures companies mainly relies on brokerage business. However, some companies started to seek restructuring in the face of increasingly serious market homogeneity competition. In mid-2012, relevant documents were issued to approve the provision of risk management services by the futures industry through the establishment of subsidiaries. As of the end of July 2016, 50 futures companies in the industry have completed the pilot filing of risk management companies.

(3) Futures Risk Management Subsidiaries can make full use of their professional research capabilities as well as the advantages of spot and futures channels to provide risk management services for entities and realize the purpose of hedging risks. However, it is undeniable that the futures companies themselves have accumulated considerable risks while conducting their risk management businesses. Futures companies can better serve the real economy and transform their businesses only if their own risks can be controlled. In addition, futures company another more prominent innovative business asset management. Given the rapid growth of wealthy people in the current world, the wealth management market has a bright future. Futures companies carrying out wealth management business are one of the important ways to achieve a successful transition. As the core content of wealth management, as of the end of June 2016, the scale of asset management of futures companies was 227.3 billion $\mathrm{RMB}$, an increase of $62.59 \%$ over the first quarter of the year.

(4) The pace of development was clear. However, the main purpose of the wealth management business is to formulate a personalized financial planning for the customer and comprehensively consider the assets and liabilities in order to achieve the continuous accumulation of wealth. Therefore, the requirements on the risk management ability of the futures business of the business are further required. In general, efficient risk management and control are the preconditions for the innovation and development of the futures companies and the overall transformation [10]. 


\subsection{Futures Company Risk Management Status Quo Analysis}

(1) Industry regulation is gradually strengthened. Chinese futures industry by the SFC to implement unified supervision, in the early stages of development play an effective integrated planning, but with the continuous development of the futures market, the original regulatory model does not fully meet the needs of the futures company's development, the risk of Control is also relatively lagging behind. According to the interim statistics data, the net capital of the futures industry as a whole showed a trend of increasing year by year. In 2015, the total net capital reached 600.38 billion RMB, up $27.07 \%$ over the same period of the previous year, of which Yong'an Futures topped the industry with net capital of about 2.8 billion RMB, But the minimum net capital is only 18 million RMB, the difference is obvious. Due to the rapid expansion of the futures market in recent years, the current regulatory system can no longer completely cover the new risks arising from the innovative businesses such as asset management and risk management of futures companies. Therefore, in 2016, the CSRC revised the "Administrative Measures" in order to strengthen its control over the futures industry, and clearly set out the minimum capital requirement of 30 million RMB. Although there is still a large gap between the current situation of the futures industry and the overall situation, the current futures industry plays an important guiding role, which can significantly reduce the operational risk of the industry. In addition, in this approach, the Commission also included early warning standards into risk supervision indicators and adjusted the scope and standards of provision for venture capital risk management to further clarify the risk control aspects of futures companies. Overall, the regulatory model of the futures industry is gradually being improved, with a tightened approach and full supervision according to law.

(2) The internal wind control mechanism lags behind. The main end point of the corporate governance structure of futures companies is risk prevention, which mainly includes the third-level supervision department of shareholders' meeting, board of directors and board of supervisors, which manages and supervises the specific business activities of the company. However, the current governance structure promotes the promotion of corporate risk management the role is not obvious, the specific operation is still there, such as to keep the customer sticky and relax the deposit requirements and other non-standard behavior, the reason is the risk management costs and the impact of competitive pressures in the industry. At present, the futures business of our country mainly focuses on the brokerage business. The risk control focuses on the margin system and the means are relatively single, and its risk management autonomy is not strong. It is often passively accepted by regulators to promote risk management. Therefore, although the futures companies have formulated the internal control system at the request of the CSRC, most of them are mere formalities and do not fully adapt to the actual operation of the company. Therefore, the implementation of the futures companies is not strong. Under the trend of innovation and development, the risks of futures companies are further enlarged, but their risk management construction is in a relatively backward state with some gaps with the regulatory requirements, hindering their own sustainable development.

The current futures companies a single means of risk management, risk control mechanisms need to be improved. When market conditions change and pose a potential threat to the company, the futures companies often find it hard to take precautionary measures. The risk control measures are limited to events and ex post phases such as margin calls and forced liquidation. A sound risk control mechanism should be covered All stages, to achieve a full range of risk management and control, it is clear that the futures companies in our country remain flawed in the early stages. The risk control early warning requires that futures companies have a global sense of risk control and conduct reasonable risk aversion operations in the early stages of futures trading, such as investor education. Due to the particularity of futures trading, the leverage effect further expands the risk of the transaction. Investors should focus on diversification of risks in the investment process. However, because most investors are not highly professional, the futures company should make relevant guidance to its clients to popularize futures investment risks and guide them to participate in different types of futures investments. However, it is clear that the measures taken by Chinese futures companies in this regard are not in place. For example, the risk margin adjustment methods 
such as adjusting the margin ratio and limiting positions are also rarely used in futures trading , Showing that the corporate management's overall awareness of risk is not high, and the risk control mechanism is not perfect. Second, apart from the awareness of risk, the risk analysis and assessment methods of the current futures companies are also relatively simple. They mainly rely on inspection or qualitative research to make subjective analysis on risk, which is not enough in quantitative research and risk control model construction.

\section{The Futures Company's Risk Management and Control Strategy}

\subsection{Empirical Analysis of Futures Company Risk Management}

(1) Analysis of the supervision mode of international futures industry. Initially, South Korea implemented separate regulation on the financial sector. The main regulatory bodies included supervisory boards such as banks, securities, insurance and non-bank financial institutions. However, with the increasing trend of mixed operation, South Korea has gradually tended to be supervised. Currently, the futures industry in South Korea is mainly under the supervision of the Financial Supervisory Commission and its securities and futures management committee. The former exercises inspections of specific operating activities such as exchanges, trade associations and futures companies and provides protection for the rights and interests of investors. The latter the main responsibility lies in the formulation of policies, amendments to the law, a clear definition of the scope of the futures companies and industry associations. Japan, on the other hand, adopts the functional supervision model and establishes a high degree of authority to guarantee supervision through a sound legal system, including national laws, departmental laws and regulations and local laws and regulations. Under the supervision mode, division of departments by industry can maximize the level of professional staff, so that the separation of supervision and functional supervision is highly integrated. In addition, there is no separate futures trade association in Japan. However, a variety of commodity exchange federations actually play the role of the former, coordinate the interests between the exchanges and safeguard the rights and interests of investors. In general, all countries have gradually shifted their regulatory mode from one industry to another and gradually formed a system of three-tier supervision covering the government, the industry itself and the futures exchanges. The coordination between the regulatory agencies is strong and the regulatory efficiency Higher, for our country's futures industry regulation has a positive reference.

(2) Analysis of commercial banks risk management. As a mature financial institution, commercial banks have considerable advantages in terms of risk control. Basel agreements can be borrowed from futures companies because they clearly regulate the industry's common risk management standards and cover market risks, operational risks and three specific risks of credit risk and with the minimum capital requirements, supervision and inspection and market constraints as a framework for commercial banks to guide the business activities. For the prevention of credit risk, commercial banks have fully absorbed the advanced experience from abroad, minimized the risk by credit rating and real-name management of customers, and classified the loan quality in the specific operation process in order to timely control the risk . In addition, the Basel Accord also makes a series of methodological suggestions on bank credit risk assessment, such as the standard method and the internal rating method. Second, commercial banks also have considerable experience in market risk. They mainly focus on strictly controlling various business risks and implementing the risk control system in each specific business. In addition, in response to the operational risk of commercial banks, Chinese CBRC also issued "Guidelines" to guide risk identification, quantification, control and other aspects. Thus, commercial banks do have considerable advantages in terms of risk management and have a strong sense of risk in all aspects of external supervision and internal control. Therefore, it is of considerable reference to the risk management of futures companies.

\subsection{Strategy Research on Promoting the Risk Management of Futures Company in China}

(1) Improve the external supervision system of futures companies. At present, Chinese futures 
market adopts a three-level supervision system, that is, a regulatory system mainly based on the three-level regulatory agencies of the CSRC, the Mid-term Association and the Exchange. Among them, the CSRC is mainly responsible for macro-control of the futures market and is mainly responsible for promoting self- Formation, the futures exchange is the implementation of front-line monitoring. Overall, the three-tier regulatory mechanism meets the development needs of Chinese futures industry, but there are still many problems. The unclear status of the CSRC's supervision and management and the obscure legal status have caused the CSRC to have obstacles in the issuance of relevant directives and are not able to exert strong deterrent effects in investigating and collecting evidence and in investigating and handling violations of laws and regulations. Therefore, a separate regulatory department for the futures industry should be established to clarify its regulatory powers and responsibilities at the legal level so that its regulatory activities can be implemented according to law. Second, the current allocation of rights of the CSRC also has some problems. Its handling of violations of the futures trading law is limited to administrative penalties. If the punishment is low, it cannot serve as a wake-up call and cannot effectively regulate the operation of the market. Therefore, the regulatory agencies should be clear at the same time should also strengthen the penalties for violations, increase default costs, and then guide the industry's normative operations.

(2) Establish a long-term risk control mechanism. The current futures company's risk control mechanism lags behind, and cannot fully meet the needs of business transformation. Therefore, futures companies need to establish a long-term risk management mechanism, advocate the construction of compliance culture, and concretely implement the measures to all levels and departments. At the same time, strengthening the internal control system is also one of the countermeasures to reduce the risk threat. Futures companies need to raise their awareness of risks, clarify the impact of potential events on corporate risks in the company's strategic objectives, and on this basis, formulate specific measures for each risk to reduce The degree of risk or to achieve the effect of avoiding the risk, at the same time need to pay attention to the inherent risk and the risk of random differences, make targeted. Effective risk control also depends on the improvement of the risk control system. Futures companies should make clear institutional rules and regulations on business and their corresponding risks, sort out business processes and implement compliance management so that all departments in the company can communicate with each other flexibly Motorized control effect. In addition, the futures company should also establish a risk control and punishment mechanism and establish a compliance assessment program, with particular emphasis on the determination of compliance targets. Compliance risk indicators should be specifically divided into important and general impact indicators, the former refers to the company's compliance management has played a significant role in the index, including the penalties suffered by the regulatory authorities; the general impact indicators are affecting the company's normal operations, By the regulatory authorities concerned or the negative public comments caused by the loss. The specific management of the risks of the futures company through the internal assessment mechanism of the index evaluation is conducive to enhancing the operability of the measures.

(3) Reasonable adjustment of business structure. Futures companies to channel business as the main business mode of operation so that it faces fierce homogenization of competition, to some extent, also amplified operational risk, and the current rapid growth of domestic high-net-worth individuals, the real economy lacks a reasonable risk aversion channel Therefore, innovative businesses such as risk management and wealth management have become important directions for the transformation and development of the futures industry. They provide new profit growth points for futures companies and enhance their market competitiveness while diversifying their business risks. Asset management business is the core of the wealth management business. Futures companies can lay a solid foundation for the latter based on the basic business represented by the former, and should also strengthen their R \& D capabilities to provide high-quality, personalized financial choice, focus on customer satisfaction. The risk management business is the futures company to take advantage of the dominant position of the industry for the risk of hedging business entities in the business to achieve the minimum risk to customers at the same time should be strictly 
controlled the company's own risks and make their business processes more smoothly, Clearly, in order to promote the company's business structure adjustment, reasonable risk diversification.

(4) improve the futures corporate governance structure. At present, the futures companies in our country have initially established the governance structure. However, they did not play a good role in risk management during the specific management. The shareholders' committee, the board of supervisors and the board of directors did not exert the best internal supervision effect. The internal control system was only in the form of root causes the current futures company's equity structure is set unreasonable, the board of directors institutions virtual, and lack of effective internal reward and punishment mechanism. Therefore, improving the corporate governance structure should combine the particularity of the futures industry and the generality of corporate governance, implement the responsibilities and powers of various departments in risk management and build a governance structure centered on the board of directors. The specific measures are to optimize the structure of the shareholding structure and avoid corporate risks arising from over-centralization; to strengthen the authority of the board of directors and strictly control the professional ethics standards of directors; to improve the information disclosure mechanism so as to control the risk from time to time; and to establish the leadership and managers Restraint mechanism, clarify the concept of power and authority; implement the chief risk officer system and emphasize the overall awareness of risk management and control.

(5) Strengthen internal staff management. Operational risk is a major risk faced by futures companies. Practice standards and ethics of practitioners play a crucial role in the management of futures companies. In the past, major futures incidents caused by mistakes of employees were not uncommon. Therefore, strengthening the management of employees is an important measure for futures companies to effectively deal with operational risks. On the one hand, futures companies should enhance their employees 'awareness of practicing, incorporate their codes of practice into employee training content, realize the warning function to employees through case study, and strengthen the assessment of employees' professional ethics. On the other hand, we will strengthen training for employees' professional qualities, raise their awareness of innovation and development, pay attention to the cultivation of comprehensive talents, and lay the foundation for the transformation of the company's business. In addition, the establishment of the relevant examination and incentive mechanism to enhance the enthusiasm of staff and sense of responsibility, the weakening of the traditional assessment model based on trading volume as the main assessment indicators, focusing on customer satisfaction and other indicators, in order to reduce the possibility of operational errors, but also to enhance staff The enthusiasm of its work lay the foundation for the transformation and development of futures companies.

\section{Conclusions}

Futures companies are the bonds between futures traders and futures markets. They trade smoothly and accumulate multiple risks, such as the credit risk of investors, the market risk in the futures market and the operational risks of employees in the company. Risk control not only plays a crucial role in the sustainable management of futures companies, but also serves as a prerequisite for business innovation in futures companies in the context of serious market homogenization competition. At present, Chinese supervision of the futures industry mainly relies on China Securities Regulatory Commission, the medium-term Association and the Exchange, although there are still some regulatory flaws, but the overall regulatory environment is increasingly optimized for futures companies to make clear the risk management guidance to make it more operational However, the internal risk management framework of futures companies is still in a mere formality. The establishment of internal control system only for coping with regulatory considerations leads to problems such as imperfect governance structure, single risk control measures, and lack of risk control links. Therefore, how to enhance the company's risk control awareness and achieve effective risk control is a major operational problem for the futures industry. In this regard, on the one hand, improve the external regulatory environment, the establishment of an independent regulator of the futures industry, and to clarify its regulatory responsibilities so that regulatory activities can be 
regulated. On the other hand, starting from the point of view of the futures company, building a compliance culture and putting the risk into specific business links; improving the corporate governance structure, giving full play to the regulatory functions of the board of directors, the board of supervisors and the shareholders' meeting on operating activities; reasonably adjusting the business structure and developing innovation Business diversification risks; strengthen the training of practitioners to improve their sense of responsibility to reduce operational risk.

\section{References}

[1] Zhang Pei RMB. On futures companies risk management [J]. Shanghai Enterprises, 2008 (10): 48-50.

[2] Guo Rui. Analysis of the risk management of Chinese futures companies [J]. Science and Technology Information Development and Economy, 2005 (4): 120-121.

[3] Li Yan. Research on Risk Management of Sales Department of Futures Companies [J]. Business, 2015 (25): 9.

[4] Huang Xiaolong, Tian Zheng. Analysis on Risk Management of Chinese Futures Companies [J]. Price Theory and Practice, 2010 (7): 55-56.

[5] Chen Yueming. Analysis on Risk Management of Futures Companies [J]. Management Management Awards, 2015(7): 144.

[6] Zhao Xianghua of Chinese futures brokerage firm risk management discussion [J]. Economist, 2011 (3): 81-82.

[7] Tian Tian, Zhao Jingjing. On Chinese futures companies risk control and industry regulation [J]. Economic Research Journal, 2014(30): 120-121.

[8] Zhang Jinyu. Analysis of futures firm service entity enterprise risk management [J]. Economist, 2012(8): 60-61.

[9] Yi Yang. Firstly, the identification of financial risks in Chinese futures companies and countermeasures [J]. News Economy, 2013(23): 157-158.

[10] Lu Minfeng, Yang Liang. Research on the Integration and Driving Forces of Internet Finance and Real Economy [J]. Journal of Tianjin University of Commerce, 2016(1): 3-7. 